\title{
EFEKTIVITAS METODE BERNYANYI BERBANTUAN MEDIA AUDIOVISUAL TERHADAP PENGUASAAN KOSAKATA BAHASA INGGRIS ANAK KELOMPOK B
}

\author{
Iftaturrohmah $^{a, 1}$, Nanik Yuliati ${ }^{b, 2}$, Suhartiningsih ${ }^{c, 3}$ \\ $\mathrm{a} b \mathrm{c}$ Universitas Jember, Indonesia \\ ${ }^{1}$ iftaturrohmah@gmail.com, ${ }^{2}$ nanikyuliati.fkip@unej.ac.id, ${ }^{3}$ suhartiningsih.fkip.unej@gmail.com
}

\begin{tabular}{l}
\hline Informasi artikel \\
\hline Received : \\
Januari 17, 2022 \\
Revised :
\end{tabular}

Februari 13, 2022

Publish :

Maret 03, 2022

Kata Kunci :

Beryanyi;

Media

Audiovisual;

Kosa kata Bahasa Inggris

\section{Keywords:}

Singing;

Audiovisual

Media;

Vocabularies

English;

\begin{abstract}
ABSTRAK
Penelitian ini dilakukan pada kelompok B TK Dharma Wanita Tembokrejo Muncar Banyuwangi. Latar belakang diadakannya penelitian ini karena masih banyak anak-anak yang kebingungan dan belum bisa menunjukkan secara jelas bahasa Inggris yang telah diucapkan oleh guru sehingga perlu mengoptimalkan penguasaan kosakata bahasa Inggris dengan menggunakan media audiovisual berupa video. Penelitian ini bertujuan untuk mengetahui efektif atau tidaknya penggunaan media audiovisual terhadap penguasaan kosakata bahasa Inggris pada kelompok B. Jenis penelitian yang digunakan adalah eksperimen quasi dengan rancangan Non-Equivalent Control Group. Sampel dalam penelitian ini adalah anak kelompok B dengan jumlah sampel sebanyak 24 responden. Metode pengumpulan data menggunakan tes, observasi dengan check list serta dokumentasi. Hasil penelitian yang diperoleh dari hasil pretest dan posttest pada kelompok eksperimen dan kontrol sebelum dan sesudah diberikannya perlakuan terdapat perbedaan yang signifikan. Hasil beda pretest dan posttest pada kelompok eksperimen sebesar 34,89, kelompok kontrol sebesar 25 sehingga diperoleh $t_{\text {hitung }}=2,778$ dan $\mathrm{t}$ tabel dengan $\mathrm{db}$ $=22$ pada taraf signifikansi $5 \%$. Nilai $t_{\text {hitung }}$ lebih besar dari t tabel $(2,778>2,074)$, hal tersebut menunjukkan bahwa ada perbedaan penguasaan kosakata antara anak yang diberikan perlakuan menggunakan media audiovisual dengan anak yang tidak diberikan perlakuan menggunakan media audiovisual.
\end{abstract}

ABSTRACT
This research was conducted in group B TK Dharma Wanita Tembokrejo Muncar Banyuwangi. The background of this research is because there are still many children who are confused and cannot clearly show the English that has been spoken by the teacher so it is necessary to optimize the mastery of English vocabulary by using audiovisual media in the form of video. This study aims to determine whether the use of audiovisual media is effective or not on the mastery of English vocabulary in group B. The type of research used is a quasi-experimental design with a NonEquivalent Control Group. The sample in this study were group B children with a total sample of 24 respondents. Methods of data collection using tests, observations with check lists and documentation. The results obtained from the results of the pretest and posttest in the experimental and control groups before and after the treatment there were significant differences. The results of the difference between the pretest and posttest in the experimental group were 34.89, the control group was 25, so that tcount $=2,778$ and t table with $d b=22$ at a significance level of $5 \%$. The value of tcount is greater than ttable $(2,778>2,074)$, it shows that there is a difference in vocabulary mastery between children who are treated using audiovisual media and children who are not treated using audiovisual media.

This work is licensed under a Creative Commons Attribution-ShareAlike 4.0 International License. Allows readers to read, download, copy, distribute, print, search, or link to the full texts of its articles and allow readers to use them for any other lawful purpose. 


\section{PENDAHULUAN}

Undang-undang Nomor 20 Tahun 2003 tentang Sistem Pendidikan Nasional menyatakan bahwa pendidikan adalah usaha sadar dan terencana untuk mewujudkan proses pembelajaran agar peserta didik secara aktif mengembangkan potensi dirinya untuk memiliki kekuatan spiritual keagamaan, pengendalian diri, kepribadian, kecerdasan, akhlak mulia, serta ketrampilan yang diperlukan dirinya, masyarakat, bangsa, dan Negara.

Pendidikan bagi kehidupan manusia merupakan kebutuhan mutlak yang harus dipenuhi. Tanpa pendidikan akan mustahil bagi suatu kelompok (manusia) dapat hidup berkembang sejalan dengan keinginan untuk maju dan hidup sejahtera menurut konsep pandangan hidup mereka. Aktivitas pendidikan terdapat fungsi dan tujuan dilaksanakannya suatu kegiatan pendidikan yang tercantum dalam Undang-undang Nomor 20 Tahun 2003 tentang Sistem Pendidikan Nasional, pendidikan nasional berfungsi mengembangkan kemampuan dan membentuk watak serta peradaban bangsa yang bermartabat dalam rangka mencerdaskan kehidupan bangsa, bertujuan untuk berkembangnya potensi peserta didik agar menjadi manusia yang beriman dan bertakwa kepada Tuhan Yang Maha Esa, berakhlak mulia, sehat, berilmu, cakap, kreatif, mandiri, dan menjadi warga negara yang demokratis serta bertanggung jawab.

Anak adalah manusia kecil yang memiliki potensi dan kemampuan. Semua potensi yang dimiliki anak masih harus dikembangkan secara optimal agar dapat berkembang dengan sebaik-baiknya. Anak juga mempunyai krakteristik sendiri yang khas dan unik yang tidak sama dengan orang dewasa serta akan berkembang menjadi manusia seutuhnya. Pada masa usia dini, terdapat beberapa masa yang perlu diketahui oleh seorang pendidik atau orang tua salah satunya masa bereksplorasi orang tua atau orang dewasa harus memahami pentingnya eksplorasi bagi anak. Biarkan anak memanfaatkan benda-benda yang ada disekitarnya dan biarkan anak melakukan trial dan eror yang menjadi hal pokok dalam belajar.

Anak usia dini merupakan masa yang tepat untuk melakukan pendidikan. Pada masa ini anak sedang mengalami proses pertumbuhan dan perkembangan yang luar biasa. Anak belum memiliki pengaruh negatif yang banyak dari luar atau lingkungannya. Dengan kata lain, orang tua maupun pendidik akan lebih mudah mengarahkan anak menjadi lebih baik. 
Anak usia dini merupakan anak yang berada dalam proses pertumbuhan dan perkembangan yang bersifat unik (Mursid, 2015). Pendidikan pada anak usia dini lebih terfokuskan pada enam perkembangan yaitu sosial-emosional, kognitif, fisik motorik, moral agama, Bahasa dan seni. Enam perkembangan tersebut harus diterapkan semua pada anak untuk mencapai semua aspek pertumbuhan dan perkembangan agar pembelajaran dapat mencapai hasil yang optimal. Untuk itu, guru harus memperhatikan setiap aspek pertumbuhan dan perkembangan pada anak usia dini terlebih dahulu agar memudahkan bagi seorang guru untuk menentukan model pembelajaran dan metode pembelajaran yang cocok untuk diterapkan.

Pendidikan Anak Usia Dini merupakan salah satu bentuk penyelenggaraan pendidikan yang menitikberatkan pada peletakan dasar ke arah pertumbuhan dan perkembangan fisik (koordinasi motorik halus dan kasar), kecerdasan (daya pikir, daya cipta, kecerdasan emosi, kecerdasan spiritual), sosio emosional (sikap dan perilaku serta beragama), bahasa dan komunikasi, serta dengan keunikan dan tahap-tahap perkembangan yang dilalui oleh anak usia dini. Pendidikan pada anak usia dini perlu adanya suatu pendekatan dalam proses pembelajaran yang berorientasi pada kebutuhan, perkembangan, belajar sambil bermain, pembelajaran aktif, kreatif, efektif, dan menyenangkan, pembelajaran terpadu, serta pengembangan keterampilan hidup. Semua itu bertujuan untuk meningkatkan aspek perkembangan anak usia dini salah satunya yaitu perkembangan bahasa dalam hal penguasaan kosakata.

Bahasa merupakan salah satu aspek yang dikembangkan sejak dini. Menurut Departemen Pendidikan Nasional Jakarta (dalam Hidayah, 2018) bahasa merupakan alat komunikasi utama yang digunakan untuk mengungkapkan berbagai keinginan maupun kebutuhan seorang anak. Bahasa yang diperoleh anak berasal dari lingkungan sekitar. Lingkungan sekitar yang dimaksud yaitu lingkungan rumah, sekolah, teman sebaya, maupun orang dewasa di sekitar tempat tinggalnya. Bahasa yang dikenalkan oleh orang tua dan lingkungan kepada anak dimulai sejak mereka lahir sampai memasuki jenjang sekolah. Bahasa merupakan bagian penting dalam kehidupan. Dengan adanya bahasa, satu individu dengan individu lainnya akan saling terhubungkan melalui proses bahasa. Badudu dalam Nilawati Tajjudin mendefinisikan bahasa sebagai alat penghubung atau komunikasi antara anggota masyarakat yang terdiri dari individu-individu yang menyatakan pikiran, perasaan dan keinginan. 
Menurutt Santrock (2014) Bahasa adalah suatu bentuk komunikasi baik yang diucpkan, ditulis atau diisyaratkan yang didasarkan pada sebuah sistem symbol Menurut Syaodih (dalam Susanto, 2011) bahwa aspek bahasa berkembang dimulai dengan peniruan bunyi dan meraban selanjutnya berhubungan erat dengan perkembangan kemampuan intelektual dan sosial. Bahasa merupakan alat untuk berpikir sedangkan berpikir merupakan suatu proses memahami dan melihat hubungan. Proses ini tidak dapat berlangsung dengan baik tanpa alat bantu, yaitu bahasa.

Menurut Syamsu Yusuf (2014) mengatakan bahwa bahasa merupakan kemampuan untuk berkomunikasi dengan orang lain. Maksudnya tercakup semua cara untuk berkomunikasi, dimana pikiran dan perasaan dinyatakan dalam bentuk lambang atau simbol untuk mengungkapkan sesuatu pengertian, seperti menggunakan lisan, tulisan isyarat, bilangan, lukisan, dan mimik muka.

Kemampuan bahasa berhubungan dengan mengolah kata atau kemampuan menggunakan kata secara efektif baik secara lisan maupun secara tertulis. Kemampuan bahasa di TK diarahkan untuk meningkatkan kemampuan anak dalam berkomunikasi dalam bahasa Indonesia dengan baik dan benar.

Salah satu bahasa yang diajarkan di TK Dharma Wanita Tembokrejo Muncar Banyuwangi adalah bahasa Inggris. Kebutuhan dan kemajuan zaman telah menuntut untuk dapat menguasai bahasa Inggris sebagai alat komunikasi di era globalisasi, sehingga bahasa Inggris dikenalkan sejak awal khususnya pada anak usia dini. Pada saat ini peran bahasa Inggris telah menjadi muatan lokal wajib. Pada umumnya pembelajaran bahasa Inggris di Taman Kanak-kanak bersifat pengenalan saja terhadap kosakata dasar yang berada di sekitar lingkungan anak, karena di dalam kurikulum pembelajaran anak usia dini harus diterapkan dengan pendekatan tematik.

Di TK Dharma Wanita Tembokrejo Muncar Banyuwangi bahasa Inggris diajarkan dengan diawali dari huruf dasar yang pada akhirnya akan disusun menjadi sebuah kata dan kalimat. Setelah anak mempelajari huruf dasar, akan memudahkan untuk memulai belajar kosakata. Pentingnya anak menguasai kosakata bahasa Inggris karena ketika mendengarkan sesuatu dalam bentuk bahasa Inggris mereka akan mudah memahami makna, serta memudahkan anak dalam pengucapannya. Hal tersebut terjadi dikarenakan guru tidak memanfaatkan media apapun untuk merangsang anak 
karena penjelasan dari guru tidak bersifat kongkret. Guru hendaknya harus membuat anak merasa tertarik dan paham dengan apa yang diajarkan, misalnya menggunakan metode dan media pembelajaran. Banyak sekali metode yang sering digunakan dalam belajar bahasa Inggris, misalnya dengan metode bernyanyi.

Menyanyi bagi anak dapat berperan sebagai wahana dalam belajar (Muliawan, 2009). Melalui nyanyian yang sesuai, perbendaharaan bahasa, kreativitas serta kemampuan anak berimajinasi, dapat berkembang dengan baik. Pada saat bernyanyi harus terdapat musik atau lagu yang menyenangkan khususnya jika akan diterapkan pada anak usia dini. Lagu yang diberikan harus menarik, kreatif dan dapat membangkitkan gairah anak dalam belajar. Media pembelajaran juga penting untuk menunjang metode bernyanyi agar berhasil diterapkan kepada anak pada saat pembelajaran, salah satunya adalah media audiovisual.

Hamdani (dalam Khotimah, 2018) menjelaskan media audiovisual merupakan media yang dapat dilihat dan didengar. Salah satu bentuk dari media audiovisual adalah video. Saat ini banyak anak-anak yang menggunakan media sosial Youtube, berupa video yang di dalamnya terdapat lagu dan gambar animasi bergerak tentang anak. Hal tersebut dapat membuat anak mendengar lirik dari sebuah lagu sekaligus mereka bisa melihat gambar-gambar animasi bergerak yang ada di dalam lagu tersebut sehingga dapat memudahkan anak untuk belajar.

\section{METODE}

Desain penelitian yang digunakan adalah penelitian eksperimen. Menurut Masyhud (2016:138) penelitian eksperimen merupakan penelitian yang dimaksud untuk mengetahui ada tidaknya pengaruh atau dampak dari suatu perlakuan (treatment) tertentu terhadap perubahan suatu kondisi atau keadaan tertentu. penelitian ini dilakukan untuk mengetahui keefektifan metode bernyanyi terhadap penguasaan kosakata bahasa Inggris pada anak kelompok B dengan media audiovisual di TK Dharma Wanita Tembokrejo Muncar Banyuwangi.

Penelitian ini menggunakan Pola eksperimental semu (quasi eksperimental) dengan rancangan "Non-Equivalent Control Group" dengan pola penelitian sebagai berikut. Pretest, Treatment dan Posttest 


\section{Kelompok Eksperimen \\ Kelompok kontrol}

\begin{tabular}{|lll|}
\hline 01 & $X$ & 02 \\
\hline 01 & & 02 \\
\hline
\end{tabular}

Gambar 3.1 Non-Equivalent control group design

Keterangan :

O1 = Observasi/Tes awal (pretest) sebelum diberikan perlakuan

$\mathrm{X}=$ Perlakuan yang diberikan kepada kelompok eksperimen

$\mathrm{O} 2$ = Observasi/Tes akhir (posttest) setelah diberikan perlakuan

(Sumber: Masyhud, 2016:165)

Populasi pada penelitian ini adalah seluruh siswa kelompok B di TK Dharma Wanita Tembokrejo Muncar Kabupaten Banyuwangi. Sampel dalam penelitian ini adalah anak kelompok B1 dan B2 dengan masing-masing kelas diambil sebanyak 12 sampel, sehingga jumlah sampel sebanyak 24 responden. Teknik pengambilan sampel yang digunakan tidak dipilih secara random atau acak, melainkan ditentukan oleh peneliti. kelas B1 sebagai kelompok eksperimen sedangkan kelas B2 sebagai kelompok kontrol. Metode pengumpulan data dalam penelitian ini meliputi 1) Tes secara lisan mengenai penguasaan kosakata bahasa Inggris, 2) Observasi berupa checklist, 3) Dokumentasi berupa data pendukung yang diperlukan dalam penelitian seperti RPPH, foto kegiatan penelitian, daftar nama anak dan lain sebagainya. Analisis data yang digunakan adalah uji statistik T-test untuk sampel terpisah dengan rumus sebagai berikut.

$$
t=\frac{M_{2}-M_{1}}{\sqrt{\frac{\sum x_{1}^{2}+\sum x_{2}^{2}}{N(N-1)}}}
$$

Keterangan:

$\mathrm{M}_{-1}=$ Nilai rata-rata kelompok X-1 (kelompok eksperimen)

$\mathrm{M}-2$ = Nilai rata-rata kelompok X-2 (kelompok kontrol)

$\mathrm{X}-1=$ Deviasi setiap nilai $\mathrm{X}-1$ dari rata-rata $\mathrm{X}-1$

$\mathrm{X}-2=$ Deviasi setiap nilai $\mathrm{X}-2$ dari rata-rata $\mathrm{X}-2$

$\mathrm{N} \quad=$ Banyaknya subyek/sampel penelitian

(Sumber: Masyhud, 2016:382)

\section{PEMBAHASAN}

Berdasarkan pelaksanaan pretest pada kelompok eksperimen diperoleh hasil sebesar 718,75 dengan rata-rata 59,89 sedangkan pada kelompok kontrol diperoleh 
hasil sebesar 687,5 dengan rata-rata sebesar 57,29. Perolehan nilai didapat dari penilaian pada kemapuan masing-masing anak.

Hasil uji pretest digunakan sebagai uji normalitas dan uji homogenitas. Hasil uji normalitas diperoleh nilai signifikansi pada kelompok eksperimen sebesar 0,137 sedangkan pada kelompok kontrol sebesar 0,123. Hasil tersebut kemudian dikonsultasikan dengan taraf signifikansi 5\% dan nilai tersebut lebih besar dari 0,05 jika ditulis $0,137>0,05$ dan 0,123>0,05, sehingga penguasaan kosakata bahasa Inggris tersebut berdistribusi normal. Selanjutnya adalah uji homogenitas yang diperoleh nilai sebesar 0,660 kemudian dikonsultasikan dengan taraf signifikansi 5\% dan nilai tersebut lebih besar dadi 0,05 jika ditulis 0,660, sehingga dapat dikatakan bahwa penguasaan kosakata bahasa Inggris antara kelompok B1 dan B2 bersifat homogen.

Hasil perhitungan terakhir yaitu analisis statistik T-test untuk menguji hipotesis dengan perhitungan sebagai berikut.

$$
\begin{aligned}
& \mathrm{t}=\frac{\mathrm{M}_{2}-\mathrm{M}_{1}}{\sqrt{\frac{\sum \mathrm{x}_{1}^{2}+\sum \mathrm{x}_{2}^{2}}{\mathrm{~N}(\mathrm{~N}-1)}}} \\
& \mathrm{t}=\frac{25-34,89}{\sqrt{\frac{895,16+781,25}{12(12-1)}}} \\
& \mathrm{t}=\frac{-9,89}{\sqrt{\frac{1.676,41}{12(11)}}} \\
& \mathrm{t}=\frac{-9,89}{\sqrt{\frac{1.676,41}{132}}} \\
& \mathrm{t}=\frac{-9,89}{\sqrt{12,07}} \\
& \mathrm{t}=\frac{-9,89}{3,563} \\
& \mathrm{t}= \pm 2,778
\end{aligned}
$$

Berdasarkan hasil uji-T diperoleh hasil thitung sebesar 2,778 Hasil tersebut kemudian dikonsultasikan dengan $t_{\text {tabel. }}$. Diketahui $\mathrm{df}=\mathrm{n}-2(24-2)=22$ pada taraf signifikansi $5 \%$, sehingga $t_{\text {tabel }}=2,074$. Berdasarkan hasil tersebut dapat diketahui bahwa hipotesis nihil $\left(\mathrm{H}_{0}\right)$ ditolak dan hipotesis alternatif $(\mathrm{Ha})$ diterima yang artinya 
terdapat keefektifan metode bernyanyi berbantuan media audiovisual terhadap penguasaan kosakata bahasa Inggris pada anak kelompok B di TK Dharma Wanita Tembokrejo Muncar Banyuwangi.

Berdasarkan dari hasil perhitungan data dalam penelitian ini menunjukkan bahwa terdapat keefektifan metode bernyanyi berbantuan media audiovisual terhadap penguasaan kosakata bahasa Inggris anak. Penggunaan metode bernyanyi berbantuan media audiovisual memudahkan guru dalam menyampaikan materi pembelajaran secara lebih optimal sehingga penguasaan kosakata bahasa Inggris anak bertambah. Media ini diterapkan 20 menit sebelum kegiatan inti dimulai, sehingga pada saat kegiatan inti berlangsung anak-anak diberikan pertanyaan mengenai lagu bahasa Inggris yang ada pada video.

Fadillah dkk. (dalam Putri, 2018) menjelaskan adanya kegiatan pembelajaran dengan bernyanyi mampu meningkatkan semangat anak dan merangsang perkembangan dalam berbahasa dan berinteraksi dengan lingkungannya. Dapat digambarkan bahwa anak-anak tidak terlepas dari dunianya yaitu bernyanyi. Anakanak sangat suka bernyanyi karena bagi anak menyanyi sangat menghibur dari mulai bertepuk tangan hingga menari mengikuti gerakan pada lagu. Masitoh (2007) menjelaskan bahwa manfaat metode bernyanyi yaitu, meningkatkan semangat anak dalam pembelajaran, mudah mengingat materi pembelajaran, meningkatkan kepercayaan diri anak, dan mengembangkan motorik anak.

Media pembelajaran juga memiliki tujuan yaitu untuk memudahkan proses pembelajaran di kelas dan lebih meningkatkan efisiensi dalam proses pembelajaran. Manfaat media pembelajaran yaitu anak lebih tertarik untuk mendengarkan penjelasan dari guru dan melihat secara langsung bagaimana bentuk atau wujud dari apa yang sudah dijelaskan. Apabila dikaitkan dengan pendapat ahli tersebut dijelaskan bahwa metode bernyanyi sangat bermanfaat bagi pembelajaran anak tidak hanya perkembangan bahasa dalam hal penguasaan kosakata bahasa Inggris saja melainkan bermanfaat bagi perkembangan yang lainnya, sehingga dapat dikatakan bahwa metode bernyanyi berbantuan media audiovisual efektif digunakan dalam pembelajaran.

Meskipun dalam pembelajaran metode bernyanyi dengan berbantuan media audiovisual efektif terhadap penguasaan kosakata bahasa Inggris pada anak, penerapan metode bernyanyi dengan bahasa Inggris tidak selalu mudah untuk dipelajari anak 
sehingga perlu diajarkan secara perlahan-lahan. Hal tersebut perlu diarahkan oleh guru pada saat pemberian perlakuan, baik pada kelas B1 yang menggunakan media audiovisual maupun kelas B2 yang menggunakan media gambar dengan cara dilakukan secara berulang-ulang agar anak paham dengan isi lagu dan mudah dalam mengucapkan kosakata bahasa Inggris yang dipelajari.

Hal ini dapat dilihat pada saat sebelum perlakuan rata-rata hasil yang diperoleh anak dalam hal penguasaan kosakata bahasa Inggris kelas B1 sebesar 59,89 sedangkan kelas B2 sebesar 57,29. Setelah diberikan perlakuan dengan media audiovisual kelas B1 memperoleh rata-rata hasil sebesar 94,79, sedangkan kelas B2 yang diberikan perlakuan dengan media gambar memperoleh rata-rata hasil sebesar 82,29 sehingga dari hasil tersebut dapat dijelaskan bahwa ada perbedaan hasil antara siswa yang diberi perlakuan menggunakan media audiovisual dengan yang diberi perlakuan tanpa menggunakan media audiovisual.

\section{SIMPULAN}

Berdasarkan hasil dan pembahasan, dapat disimpukan bahwa metode beryanyi berbantuan media audiovisual efektif terhadap penguasaan kosakata bahasa Inggris pada anak kelompok B di TK Dharma Wanita Tembokrejo Muncar Banyuwangi memperoleh hasil posttest kelompok eksperimen diperoleh rata-rata nilai sebesar 94,79 sedangkan kelompok kontrol sebesar 82,29. Nilai tersebut mengalami peningkatan dari hasil rata-rata pretest sebelumnya. Hal ini menunjukkan bahwa metode bernyanyi berbantuan media audiovisual yang diterapkan di kelas B1 lebih efektif digunakan sebagai media pembelajaran dalam penguasaan kosakata bahasa Inggris anak dibandingkan dengan kelompok B2 yang menggunakan metode bernyanyi berbantuan media gambar.

\section{UCAPAN TERIMA KASIH}

Peneliti mengucapkan terima kasih sedalam-dalamya kepada Allah SWT atas limpahan karunia dan hidayanya sehingga penulis dapat menyelesaikan karya ilmiah ini dan juga kepada TK Dharma Wanita Tembokrejo Muncar Banyuwangi yang yang menjadi tempat penelitian karya ilmiah ini, serta pengelola jurnal ABATA yang telah menerbitkan artikel ini. 


\section{REFERENSI}

Fadlillah. 2014. Edutainment Pendidikan Anak Usia Dini. Jakarta: Kencana Prenada Media Group

Hidayah, I. P. 2018. Pengaruh Metode Bercerita Berbasis Gambar Terhadap Penguasaan Kosakata Bahasa Inggris Pada Anak Kelompok B TK Aisyyah 9 Kecamatan Sempu Kabupaten Banyuwangi tahun ajaran 2017/2018. Skripsi. Jember: Fakultas Keguruan dan Ilmu Pendidikan Universitas Jember.

Kasihani. 2012. English For Young Learns. Jakarta. Bumi Aksara.

Khotimah, N. S. 2018. Pengaruh Penggunaan Media Audio-Visual terhadap Hasil Belajar Menyimak pada Kelompok B TK Dharma Indiria II Kecamatan Sumbersari Kabupaten Jember Tahun Ajaran 2017/2018. Skripsi. Jember: Fakultas Keguruan dan Ilmu Pendidikan Universitas Jember.

Masitoh, dkk. 2007. Strategi Pembelajaran. Jakarta: Universitas Terbuka.

Masyhud. 2016. Metode Penelitian Pendidikan. Jember: Lembaga Pengembangan Manajemen dan Profesi Kependidikan.

Muliawan, J. U. 2009. Manajemen Play Group dan Taman Kanak-Kanak. Yogyakarta: Diva Press.

Mursid. 2015. Belajar dan Pembelajaran PAUD. Bandung: Remaja Rosdakarya.

Putri, R. I. 2018. Peningkatan Penguasaan Kosakata Bahasa Inggris dengan Metode Bernyanyi pada Kelompok B Taman Kanak-Kanak Anak Sholeh Sukodono Sidoarjo. Skripsi. Surabaya: Fakultas Tarbiyah dan Keguruan Universitas Islam Negeri Sunan Ampel Surabaya.

Santrock. 2010. Psikologi Pendidikan Edisi Kedua. Jakarta: Salemba Humanika

Seniati, L., Yulianto, A., \& N.Setiadi, B. 2011. Psikologi Eksperimen. Jakarta: Indeks.

Sindoro, Alexander. 2006. Permainan Kata dan Musik, Word and Music Games. Batam: Karisma Publishing Group

Sitompul, E. Y. 2013. Teaching Vocabulary Using Flashcards And Word List. Journal of English and Education. 1(1): 52-58.

Slattery, M., \& Willis, J. 2001. English for Primary Teachers: A Handbook of Activities and Classroom Laguange. New York: Oxford University Press.

Stenberg, R.J. 2008. Psikologi Kognitif Edisi Keempat. Yogyakarta: Pustaka Pelajar.

Stephen, K.R. 2011. Kognisi Teori dan Aplikasi. Jakarta: Salemba Humanika.

Sugiyono. 2013. Metodologi Penelitian Pendidikan. Bandung: CV Alfabeta.

Susanto, A. 2011. Perkembangan Anak Usia Dini. Edisi 1. Jakarta: Prenada Media Group.

Yuliani Nurani Sujiono.2013. Konsep Dasar Pendidikan Anak Usia Dini. Jakarta: PT. Indeks

Nilawati Tadjuddin. 2014. Meneropong Perkembangan Anak Usia Dini Perspektif AlQur'an. Jawa Barat: Tim Herya Media

Syamsu Yusuf. 2014. Psikologi perkembangan anak dan Remaja. Bandung: PT Remaja Rosdakarya

Jhon W Santrock. 2013. Life Span Development. Jakarta: Erlangga 